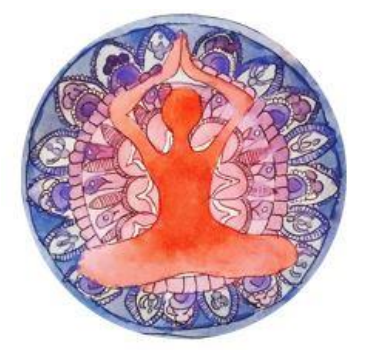

\title{
Impact of COVID-19 Pandemic on Global Healthcare Systems and the role of a new era of global collaborations
}

Parth Jain

Public Health, India

\begin{abstract}
The Covid-19 pandemic has changed the world, socially, economically and politically. There have been many positives in global scientific information flow, collaboration, speed of translation of research, technological innovation and its diffusion has been phenomenal. However the cost to human lives and livelihood has also been catastrophic.
\end{abstract}

In the post-pandemic world, the ambition to provide a well-resourced and universal health infrastructure to populations has become a challenge even for wealthy nation-states. The access to routine and elective healthcare has become severely compromised. In poorer nations, this has affected basic healthcare needs particularly for children, women and those on or below the poverty line.

Yet health is a fundamental human right, one that is guaranteed by the treatise on 'Declaration of Health for All' to which most countries are signatories. However, could the impact of this pandemic be mitigated by global health initiatives and collaboration? In this context, it is pertinent to analyse the existing global health framework and conventions to identify how we may prepare for future challenges.

\section{Keywords}

Covid-19, pandemic, global health, public health

\section{Introduction}

Due to globalisation, the mobility of the human population and urbanisation is likely to make the next emerging virus spread rapidly. It will be impossible to predict the nature of such a virus or its source and to what extent it shall spread. However, there will likely be delays in recognising and acting on such a future health threat/virus. Unusually, both developed and developing countries remain critically vulnerable. This is not the first time a health emergency has been declared by the World Health Organisation (WHO), and it will certainly not be the last.

Correspondence to; parthjain4698@gmail.com

Cite as; Jain, P. (2021) Impact of Covid-19 pandemic on global healthcare systems and the role of a new era of global collaborations. Sushruta J Health Pol vol 14; Issue 3: 1-5 epub 12.09.21 DOI: https://doi.org/10.38192/14.3.2

Article Information

Submitted 12 June 2021

Revised 11 Sep 2021

Published 12 Sep 2021 


\section{Right To Health- A Fundamental Right}

The right to health is a fundamental human right. [1] The preamble of the 1946 Constitution of the WHO defines health as "a state of complete physical, mental and social well-being and not merely the absence of disease or infirmity". The preamble further states that "the enjoyment of the highest attainable standard of health is one of the fundamental rights of each person without distinction of race, religion, political belief, economic or social condition." Since its first declaration, various international treaties and laws recognised the right to health or its sublets like the right to medical care. Every nation-state has adopted health as a fundamental right and ratified its internal treaties and policies recognising health.

Right to health is an inclusive term. It includes the basics of survival, namely air, clean drinking water or healthy food, and freedom from non-consensual medical experiments and treatments posing a risk to human life. Further, it also highlights equality when it comes to health. Non-discrimination is a key to equality and crucial for enjoying the right to the highest attainable standard of health.

\section{Right to Health and Right to be Healthy Discriminated:}

A common misconception is that the state guarantees good health. However, one fails to consider factors beyond the state's control, such as an individual's hygiene or economy. The state may provide adequate means to improve the standard of living and maintain that standard is an individual's choice. The right to remain healthy is unconditional, whereas the right to health is the enjoyment of conditions required to attain a healthy life. Moreover, no nation-state may offer a defence under the blanket of financial breakdown or a lack of resources for not recognising this right.

\section{Role of the WHO}

WHO is the directing and coordinating authority for health within the United Nations.[2] It is responsible for providing leadership on global health matters and collaboration across the many health systems across the globe. In the 21st century, health is a shared international responsibility, allowing equitable access to essential care and collective defence against transnational threats. The WHO was established during World War -II [3] and had been striving to establish conventions, agreements and recommendations concerning international health matters.[4] It also actively participates in the research of various epidemic diseases and props humanity in fighting against them.[5] The WHO is also responsible for framing various policies and agreements to set out international health standards and define a healthy life. The most historic responsibility that WHO takes up is the international control of the spread of disease.[6]

\section{International Health Regulation}

The International Health Regulations (IHR 2005) adopted by the World Health Assembly came into force in June 2007. These regulations are binding on 194 state parties and all the members of the WHO.[7] This regulation is the successor of the International Sanitary Regulations 1951 that was renamed and reframed to International Health Regulations 1969, further revised to International Health Regulations 2005. This instrument protects the states from the outbreak of disease, public health risks and public health emergencies.[8] The reason for IHR, as per article 2, is 'to prevent, protect against, control and provide a public health response to the international spread of disease in ways that are commensurate with and restricted to public health risks, and which avoid unnecessary interference with international traffic and trade'.

\section{Evolution Of Global Health Laws [9]}

Public health is among the earliest domains of international cooperation for which an intergovernmental organisation was created. However, the scope of international legal cooperation of public health until recently was minimal. Diseases have been the unwelcomed travelling companion of international commerce throughout history, and international public health cooperation is concerned with protecting public health. The functions of the first international health organisations of the nineteenth and twentieth centuries centred on combating infectious and communicable diseases and preventing their spread across international boundaries. For instance, the Conseil supérieur de santé (Superior Council of Health) of Constantinople, composed of delegates of the Ottoman Empire and the chief maritime states, was established in 1838 to supervise sanitary regulation of the Turkish ports to stop the spread of cholera. International disease control remained the predominant area of international legal cooperation throughout the midnineteenth century and most of the twentieth century. With attention limited to international 
disease control, public health law remained a comparatively neglected field-the WHO traditionally neglected the utilisation of international legislative strategies to publicise its global public health policies. Member states also paid little attention to the potential contribution of the law of nations in advancing global health during most of the last century.

Global health law is defined as a 'field that encompasses the legal norms, processes, and institutions needed to make the conditions for people throughout the planet to achieve the very best possible level of physical and mental health'. Within the last few decades, the global health law has expanded due to globalisation, public health diplomacy, and concerns with economic and social rights.

\section{Healthcare in the European Union \& Asia}

Every country in the European Union (EU) has its healthcare system, which has many similarities to the National Health Service in the UK and automatically includes all its citizens. In most countries, healthcare is free except for some paid services.[10] The introduction of internal markets has increased healthcare efficiency and simplified resource allocation. However, the resource pressures on the nation-states are likely to go up with increasing expectations, medical advancement and ageing populations. Many EU countries have failed to curb the inequalities in health status and rising health resource demands. As far as Asian countries are concerned, healthcare is a melange of public and privately managed programmes.[11]

\section{Covid-19 Impact on the EU [12]}

While many countries implemented an effective command and control mechanism to control and contain the emerging pandemic, the EU was largely unprepared. The stockpiles of equipment to tackle such a pandemic with infection control, personal protection, medicines, and life-support ventilators were considered inadequate. Inordinate delays were encountered in sourcing these as global trade came to a standstill. Crisis management plans fell at the altar of logistics, forcing healthcare staff to improvise and compromise, often their safety. There was a realisation that practical global cooperation in the redistribution of essential equipment was a necessity. Thus, logistics, crisis preparedness, coordination, and continuing with routine healthcare are areas that require future improvement on a global scale. There is no "ideal healthcare system", but there is a need for long-term investment in human resources and infrastructure. Public funding to provide universal access to essential healthcare is a dream of many welfare orientated nation-states such as the UK and many EU countries. However, there is a challenge to reconcile public expectations from their health service and their willingness to pay. The ideological barrier is that the healthy, younger working populace are usually reluctant to pay for the health care costs of the elderly, those that are unable to work productively and with chronic ailments. Paying for healthcare for children is an exception.

Real-time data-driven digital innovations, including continued investment in health promotion and genomics, are crucial to breaking the disease cycles, creating affordable healthcare systems, and offering universal coverage, thus improving long-term outcomes.

\section{The impact of Covid-19 in Asia [13]}

The strategy to contain the SARS-CoV-2 virus in East Asia was by using conventional containment measures, often viewed by many as 'draconian' such as in Singapore and Hong Kong. In some developing parts of the world like India and Africa, with inadequate public health infrastructure and burgeoning populace, the pandemic was tackled by public health education and non-pharmaceutical approaches such as social distancing, lockdowns, wearing masks at all times and community-led sanitising. In India, an early imposition of lockdown was a pivotal weapon to curb the spread of SARS-CoV2 virus in the first surge. The experience in the second surge in India was fuelled by a combination of religious and political decisions and a national leadership focussed on the machinations of democracy. Poverty, an under resource healthcare system and a high population remain a barrier for India to control its cases with similar conditions prevailing in Africa.

\section{Failure of the WHO}

During SARS in 2002-03 the WHO was quick enough to impose travel restrictions and criticise China for not disclosing material facts and vitals necessary to curb the effect globally.[14] After successfully eradicating SARS, the WHO warned member states about viruses and epidemics in the future and implored the international community to investigate every possible animal reservoir that could be a source for future outbreaks and also the movement of such viruses in humans. China was warned about its wet markets and restrictions were imposed. The mutable nature of viruses, coupled with China's growing urbanisation and apparent refusal to tackle the illegal trade in exotic animals, was termed a ticking 'time bomb'.[15] In 2019 when a pneumonia-like virus was detected in Wuhan [16], China, despite previous 
experience during SARS, the WHO failed to take prompt action. [17] The WHO's lack of responsiveness and leadership during the early days of the COVID-19 pandemic has compromised the faith that member-states have previously placed in it.

\section{Need For International Pandemic Treaty}

Covid-19, to date, continues to have a devastating impact on the world, with countries developing their policies and interventions, often at odds with their neighbours.[18] There are bipartite agreements implemented on sourcing life-saving equipment, and vaccine diplomacy gives way to vaccine protectionism. There is a need for a new international order in public health. Perhaps in the form of an international health treaty.

The treaty should bring nations together, dispel the temptations for protectionism and nationalism, address the challenges that could only be resolved through collaboration and rebuild trust. The French President Emmanuel Macron, German Chancellor Angela Markel and other leaders are urging all countries to be better prepared to predict, prevent, detect, assess and efficiently respond to future pandemics in an organised and professional fashion.[19]

A new treaty should mandate collaboration and sharing of research and development expertise, data and resources. The Vaccine collaborative is one area of collaboration. Many countries led by South Africa and India seek a temporary pandemic waiver to global rules protecting the technology for Covid vaccines, which wealthier countries including the United Kingdom and the USA have rejected, fearing a negative impact on the financial interests of the pharmaceutical industry. [20] Such a waiver of intellectual rights will be detrimental to future innovation. However, an international treaty on public health will be able to provide guarantees so that investment in innovations are shared equitably, and outcomes are people-oriented. While competition and incentives are essential for driving innovation, the price to humankind is too high to reject a well-designed international treaty. Perhaps the WHO will need to be reincarnated with transparency and responsiveness, which is critical for the survival of humankind. We owe it to the five million who have lost their lives in the current pandemic.

\section{REFERENCES}

1. Office of the United Nations High Commissioner for Human Rights, The Right to Health [Internet]. Fact Sheet 31 [cited 2021 June 28]. Available from: URL.
2. World Health Organisation Constitution, Article 2(a): 'to act as the directing and coordinating authority on international health work' [Internet]. Constitution Chapter II [cited 2021 June 28]. Available from: URL. 3 . The Constitution of The World Health Organisation came into force on April 7, 1948 [cited 2021 June 28]. Celebrated as 'World Health Day' [Internet]. Available from: URL.

4. World Health Organisation Constitution, Article 2(c): 'to assist the government, upon request, in strengthening health services' [Internet]. Constitution Chapter II [cited 2021 June 28]. Available from: URL. 5. The health consequences of emergencies and disasters [Internet]. Health Emergency and Disaster Risk Management Framework (2019) [cited 2021 June 28]. Available from: URL.

6. The World Health Organisation takes up the historic challenge of disease control management International Health Regulation (2005) [Internet], 3rd Edition [cited 2021 June 28]. Available from: URL. 7. The IHR are legally binding on 196 countries including the 194 member states [Internet]. International Health Regulations (2005), 3rd Edition [cited 2021 June 28]. Available from: URL.

8. Toolkit for implementation in national legislation [Internet]. National IHR focal point [cited 2021 June 2008] Available from: URL

9. Allyn Taylor, Global Health Law: International Law and Public Health Policy [Internet]. United States National Library of Medicine and National Institutes of Health [cited 2021 June 28]. Available from: URL 10. Dr.Lijy Thomas, Health Care in the European Union is absolutely free except for the subscription to its paid service [Internet]. News Medical Life Sciences [cited 2021 June 28]. Available from: URL.

11. Dr.Lijy Thomas, Health Care System in Asia [Internet]. News Medical Life Science [cited 2021 June 28]. Available from: URL.

12. Covid-19 effects on the unprepared European Union [Internet]. Inadequacy in curbing the pandemic. News Medical Life Sciences [cited 2021 June 28]. Available from: URL.

13. Response to Covid-19 in Asia [Internet]. News Medical Life Sciences [cited 2021 June 28]. Available from: URL.

14. J.S.Mackenzie, The WHO Response To SARS and Preparations For The Future [Internet]. NCBI [cited 2021 June 28]. Available from: URL.

15. Samir Saran, \#Covid19: Dr.WHO gets prescription wrong [Internet]. ORF [cited 2021 June 28]. Available from: URL.

16. World Health Organisation Report [Internet],WHO Statement regarding cluster of pneumonia cases in Wuhan, China [cited 2021 june 28]. Available from: $\underline{\mathrm{URL}}$. 
17. J.S.Mackenzie, The WHO Response To SARS and Preparations For The Future [Internet]. NCBI [cited 2021 June 28]. Available from: URL.

18. World leaders call the pandemic 'greatest test of solidarity in generation' [Internet]. The Indian Express [cited 2021 June 28]. Available from: URL.

19. Global treaty needed to protect states from pandemics, say world leaders [Internet]. The Guardian [cited 2021 June 28]. Available from: URL. 20. Emma Frage, Wealthy countries block Covid-19 drugs right waiver at WTO [Internet]. Reuters [cited 2021 June 28]. Available from: URL. 